\title{
Dependence of Total Longshore Sediment Transport Rates on Incident Wave Parameters and Breaker Type
}

US Army Corps of Engineers ${ }_{\circledast}$

by Ernest R. Smith, Bruce A. Ebersole, and Ping Wang

PURPOSE: Total longshore sediment transport (LST) rate and its cross-shore distribution in the surf zone are essential to many coastal engineering and science studies. Practical engineering applications such as predicting beach response in the vicinity of coastal structures, beach-fill evolution and renourishment requirements, and sedimentation rates in navigation channels all require accurate predictions of LST rates. Present predictive tools have been developed based primarily on field studies; however, obtaining high-quality data in the field is difficult (Wang and Kraus 1999). Arguably the most widely used model for estimating total longshore sediment transport rate is the "CERC" formula (Coastal Engineering Manual 2002, Shore Protection Manual 1984), which is based on field measurements and is often applied to calculate the total LST rate. Accuracy of the CERC formula is believed to be $\pm 30-50$ percent at best; and several parameters that logically might influence LST are excluded in the formula, such as breaker type and grain size.

This CHETN summarizes results of experiments conducted in the Large-scale Sediment Transport Facility (LSTF) (Hamilton et al. 2001; Hamilton and Ebersole 2001; Fowler et al. 1995) to investigate the importance of wave height, period, and breaker type (spilling and plunging breakers) on total LST and the cross-shore distribution of LST. The LSTF is capable of simulating wave conditions that are almost directly comparable to annual averages along many low-wave-energy coasts, for example a majority of estuarine beaches (Nordstrom 1992) and many beaches along the Gulf of Mexico and the Great Lakes in the United States.

BACKGROUND: A common tool for predicting the total rate of longshore transport is the CERC formula. The model, based on the assumption that the total longshore sediment transport rate is proportional to longshore energy flux, is given as:

$$
Q=\frac{K}{16 \sqrt{\gamma_{b}}} \rho g^{\frac{3}{2}} H_{s b}^{\frac{5}{2}} \sin \left(2 \theta_{b}\right)
$$

in which $Q$ is the total immersed weight LST rate, $K$ is an empirical coefficient, $\rho$ is density of water, $g$ is acceleration due to gravity, $H_{s b}$ is significant wave height at breaking, $\gamma_{b}$ is the breaker index, and $\theta_{b}$ is wave angle at breaking. Breaker index is often assumed to be 0.78, although it is a function of wave height, wave period, and beach slope (Weggel 1972; Smith and Kraus 1991; Rattanapitikon and Shibayama 2000). For example, breaker indices predicted with the method of Weggel (1972) ranged from 0.77 to 0.92 for the wave conditions generated in the LSTF. Although improved methods for estimating breaker index have been developed, the value of 0.78 was used in calculations of Equation 1 for simplicity in the present study. The Shore Protection Manual recommends a value of $K$ of 0.39 , which was derived from the original field study of 
Komar and Inman (1970) using sediment tracers. However, the expression is best used if the coefficient is calibrated with data for a particular site. For design applications with adequate field measurements, the CERC formula can be calibrated and applied to estimate total longshore sediment transport rates with reasonable confidence ( \pm 50 percent). However, some sites do not have adequate data available to calibrate $K$, and for design applications without calibration data the CERC formula provides only order-of-magnitude accuracy (Fowler et al. 1995; Wang et al. 1998). Miller (1998) found that the CERC formula sometimes over- and sometimes underpredicted LST rate for measurements during storms, indicating the value of $K$ also can be higher than 0.39 .

Most of the data available for calibration of empirical longshore sediment transport formulas were obtained from field measurements. Field measurements in the dynamic surf zone are noncontrollable and nonrepeatable, which may lead to large uncertainties (Schoonees and Theron, 1993, 1994; Wang et al. 1998; Wang and Kraus 1999). In addition, only a limited number of parameters can be measured in the field with coarse temporal and spatial resolutions.

The few laboratory studies on longshore sediment transport are advantageous in that they are controllable and repeatable, and therefore, should be more accurate than field data. Laboratory data have not been broadly used in the calibration of LST formulas, largely because typically small scales were used. However, Kamphuis (2002) found that experiments conducted with a relatively small model had little scale effect and uncertainties were less than that of field results. Kamphuis suggests that it is difficult to improve estimates of longshore sediment transport rate based solely on field data because of large uncertainties associated with measuring basic variables and the subjectivity of interpreting results. Kamphuis concludes that any improvements to sediment transport relationships need to be developed from controlled and controllable model tests, despite the shortcomings of physical models.

Kamphuis (1991) developed a relationship for estimating longshore sediment transport rates based primarily on physical model experiments. The equation, which Kamphuis (2002) found to be applicable to both field and model data, is expressed as:

$$
Q_{u}=2.27 H_{s b}^{2} T_{p}^{1.5} m_{b}^{0.75} d_{50}^{-0.25} \sin ^{0.6}\left(2 \theta_{b}\right)
$$

in which $Q_{u}$ is the transport rate of underwater mass in $\mathrm{kg} / \mathrm{s}, T_{p}$ is the peak wave period, $m_{b}$ is the beach slope from the breaker line to the shoreline, and $d_{50}$ is the median grain size. Kamphuis (2002) uses the same equation, but redefines the beach slope as the slope that causes breaking, i.e., the slope over one or two wavelengths offshore of the breaker line. However, the slope offshore of breaking in the LSTF is somewhat artificial because of the physical model limits. Therefore in the present study, $m_{b}$ is defined as the slope from the breaker line to the shoreline (Kamphuis 1991). Equation 2 is appealing because it includes wave period, which influences wave breaking (Galvin 1968), and grain size diameter, a relevant factor in incipient sediment motion.

Bailard (1981, 1984) developed an energy-based model based on root mean square (rms) breaking wave height. The model calculates $K$ as a function of breaker angle and the ratio of velocity magnitude to sediment fall speed. The Bailard model was calibrated with field and 
laboratory data (wave heights ranging from $0.5 \mathrm{~m}$ to $2.0 \mathrm{~m}$ ) and is similar to a relationship developed based on limited laboratory data by Walton (1979) and Walton and Chiu (1979). The Bailard equation is given as:

$$
K=0.05+2.6 \sin ^{2}\left(2 \theta_{b}\right)+0.007 \frac{u_{m b}}{w_{f}}
$$

where $w_{f}$ is the fall speed of the sediment and $u_{m b}$ is the maximum oscillatory velocity magnitude at breaking obtained from shallow-water wave theory as:

$$
u_{m b}=\frac{\gamma_{b}}{2} \sqrt{g h_{b}}
$$

The relationship was developed based on fall speeds between $0.025 \mathrm{~m} / \mathrm{s}$ and $0.205 \mathrm{~m} / \mathrm{s}$, breaker angles between $0.2 \mathrm{deg}$ and $15 \mathrm{deg}$, and $u_{m b}$ between 0.33 and $2.83 \mathrm{~m} / \mathrm{s}$. The LSTF parameters of $\theta_{b}$ and $u_{m b}$ are within the data ranges given by Bailard. The fall speed was obtained using Hallermeier (1981) for the LSTF grain size of $0.15 \mathrm{~mm}$ and is calculated to be $0.183 \mathrm{~m} / \mathrm{s}$, which is lower than the valid range given by Bailard. However, estimates of longshore sediment transport were made with the CERC formula with $K$ estimated by Equation 3 for the purpose of comparison.

del Valle, Medina and Losada (1993) developed an empirically based relationship for $K$, which shows decreasing values of $K$ with larger grain sizes. The equation was based on data presented by Komar (1988) and data obtained from the Adra River Delta, Spain. The equation, applied to rms breaking wave heights is given as:

$$
K=1.4 e^{\left(-2.5 d_{50}\right)}
$$

in which $d_{50}$ is expressed in millimeters. The relationship was developed on limited data and is strongly dependent on the relatively larger median sand grain sizes from the Adra River Delta, $\left(d_{50}=0.44 \mathrm{~mm}\right.$ to $\left.1.5 \mathrm{~mm}\right)$.

EXPERIMENT CONDITIONS: The LSTF consists of four synchronized wave generators, a sand beach composed of well-sorted sand with a median grain diameter of $0.15 \mathrm{~mm}$, an external recirculation system to minimize adverse laboratory effects created by the beach boundaries, an automated instrumentation bridge, and traps equipped with load cells to weigh transported sand. Measurements of LST were made after the beach reached a near-equilibrium condition under the prolonged influence of the prescribed incident wave conditions, and after the externally recirculated currents were adjusted to match the wave-induced longshore currents.

Four irregular wave conditions, with a relatively broad spectral shape representing typical sea conditions, were generated in the LSTF. The wave conditions were designed to obtain and compare LST rates for different breaker types by varying incident wave height and period. Four conditions generated in the LSTF are listed in Table 1, where $H_{m o}$ is the energy-based significant wave height measured near the wave makers. Furthermore, the wave conditions were grouped by 
energy level; Tests 1 and 3 had similar incident wave heights and are referred to as higher energy conditions, and Tests 5 and 6 are referred to as lower energy conditions. Each test was conducted with a water depth, $h$, of $0.9 \mathrm{~m}$ at the wave generators. Test 6 is ongoing and results presented are preliminary.

Determination of $H_{s b}$ for irregular waves is somewhat subjective. In the present study, the main breaker line was determined as the location landward of which a significantly accelerated rate of wave-height decay was measured. This criterion was based on the comprehension that a dramatic wave-energy loss, and therefore, wave height decrease, should follow dominant wave breaking. Visual observations during the experiments supported the determination.

\section{Table 1}

Longshore Sediment Transport Experiment Wave Conditions

\begin{tabular}{||l|l|l|l|l|l|l|l||}
\hline \hline Test Number & Breaker Type & $\boldsymbol{H}_{\text {mo }}, \mathbf{m}$ & $\boldsymbol{H}_{\boldsymbol{s b}}, \mathbf{m}$ & $\boldsymbol{T}_{\boldsymbol{p}}, \mathbf{s}$ & $\boldsymbol{h}, \mathbf{m}$ & $\boldsymbol{\theta}_{\boldsymbol{b}}, \mathbf{d e g}$ & $\boldsymbol{m}_{\boldsymbol{b}}$ \\
\hline \hline 1 & Spilling & 0.25 & 0.26 & 1.5 & 0.9 & 6.5 & 0.031 \\
\hline 3 & Plunging & 0.23 & 0.27 & 3.0 & 0.9 & 6.4 & 0.024 \\
\hline $6^{1}$ & Spilling & 0.16 & 0.18 & 1.5 & 0.9 & 6.7 & 0.025 \\
\hline \hline${ }^{1}$ Test 6 is ongoing & Plunging & 0.19 & 0.21 & 3.0 & 0.9 & 6.4 & 0.020 \\
\hline
\end{tabular}

Wave height distribution and the average profile associated with each experiment are shown in Figures 1 through 4 . Waves broke by spilling during Test 1, and Figure 1 shows a gradual decay of wave height through the surf zone, with incipient breaking occurring approximately $13 \mathrm{~m}$ from the shoreline. The beach profile is near planar inside the surf zone. Figure 2 shows the distribution of wave heights and profile associated with Test 3 . Test 3 waves shoaled to a height of $0.27 \mathrm{~m}$ and sharply decreased at approximately $13 \mathrm{~m}$ from the shoreline. Wave heights are similar to those of Test 1 in the inner surf zone. Test 3 waves broke by plunging as evident by the breakpoint bar and trough formed at approximately $11 \mathrm{~m}$. Test 5 waves show a gradual decrease across the surf zone $16 \mathrm{~m}$ from the shoreline (Figure 3 ). In this case, inner surf zone wave height is significantly less than observed for Tests 1 and 3 . The average beach profile of Test 1 was used as the initial profile for Test 5, and little change occurred between the two profiles. During Test 5, erosion occurred shoreward of $9 \mathrm{~m}$ from the shoreline and sand was deposited between 10 and $12 \mathrm{~m}$ from shore, and seaward of $13 \mathrm{~m}$. Figure 4 shows wave transformation and the beach profile formed during Test 6 . Waves shoaled to $0.21 \mathrm{~m}, 10 \mathrm{~m}$ from the shore, where heights sharply decreased. A small breakpoint bar (compared to Test 3 ) formed under the lower incident plunging wave conditions. 


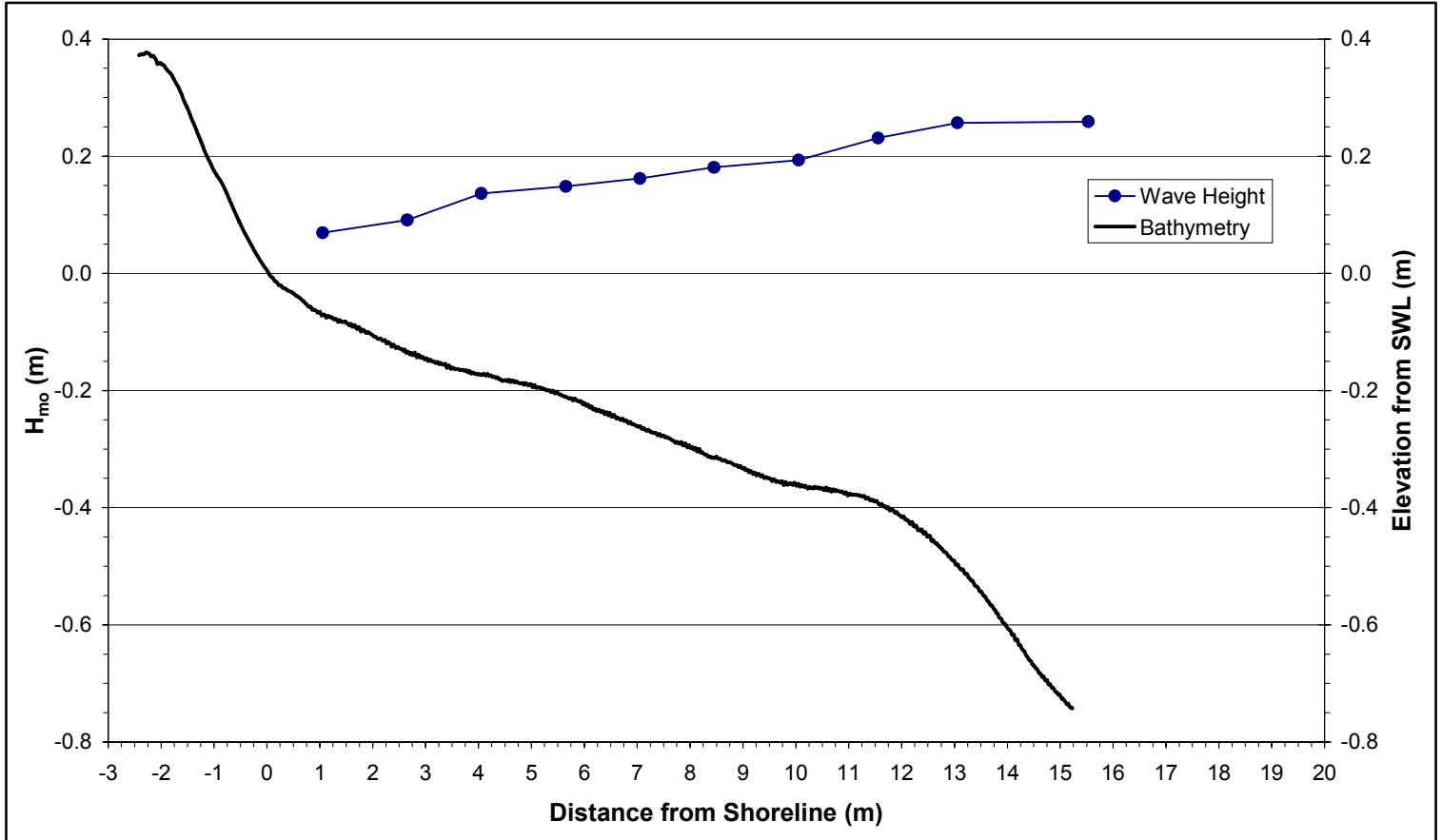

Figure 1. Wave height distribution and beach profile associated with Test 1

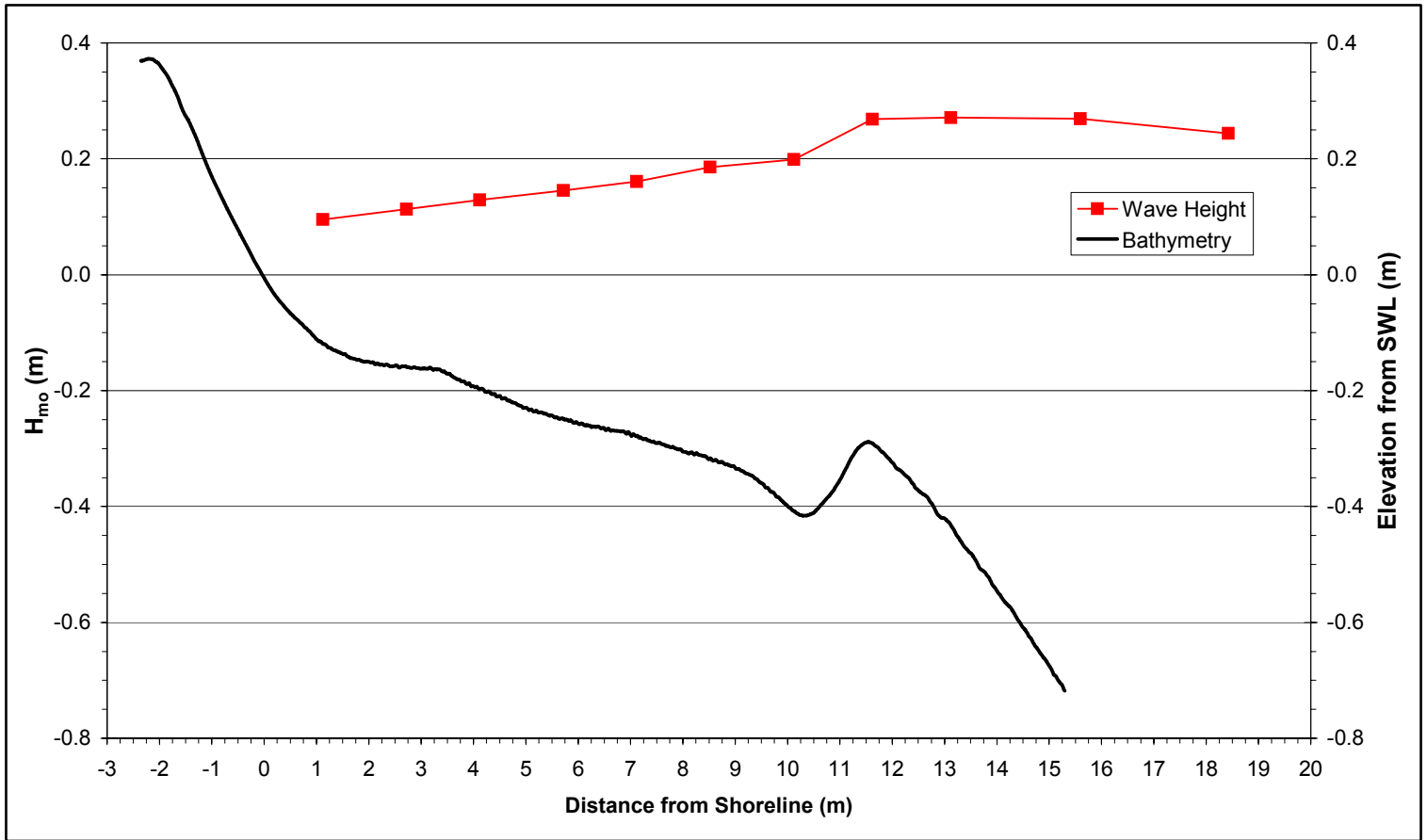

Figure 2. Wave height distribution and beach profile associated with Test 3 


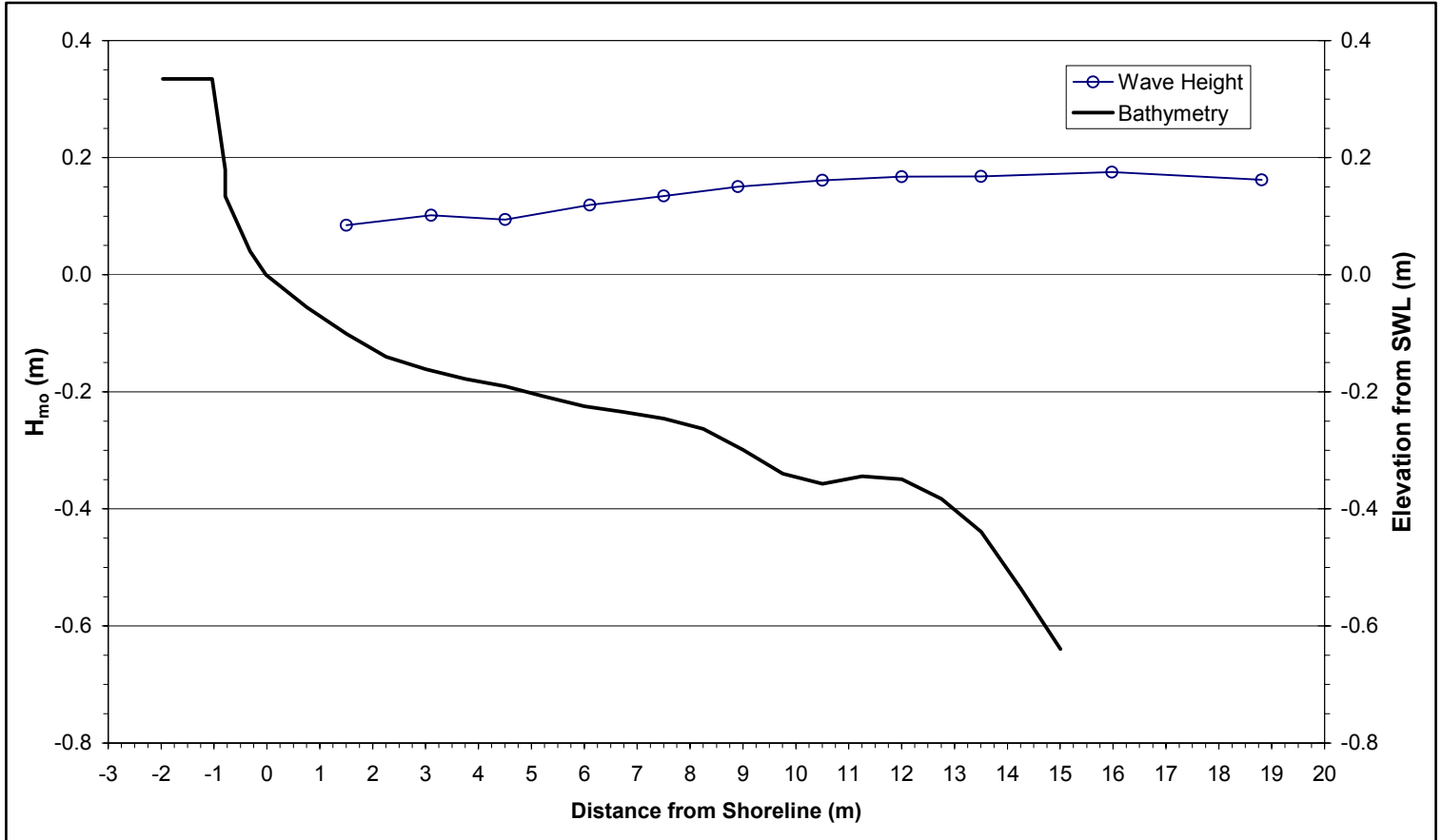

Figure 3. Wave height distribution and beach profile associated with Test 5

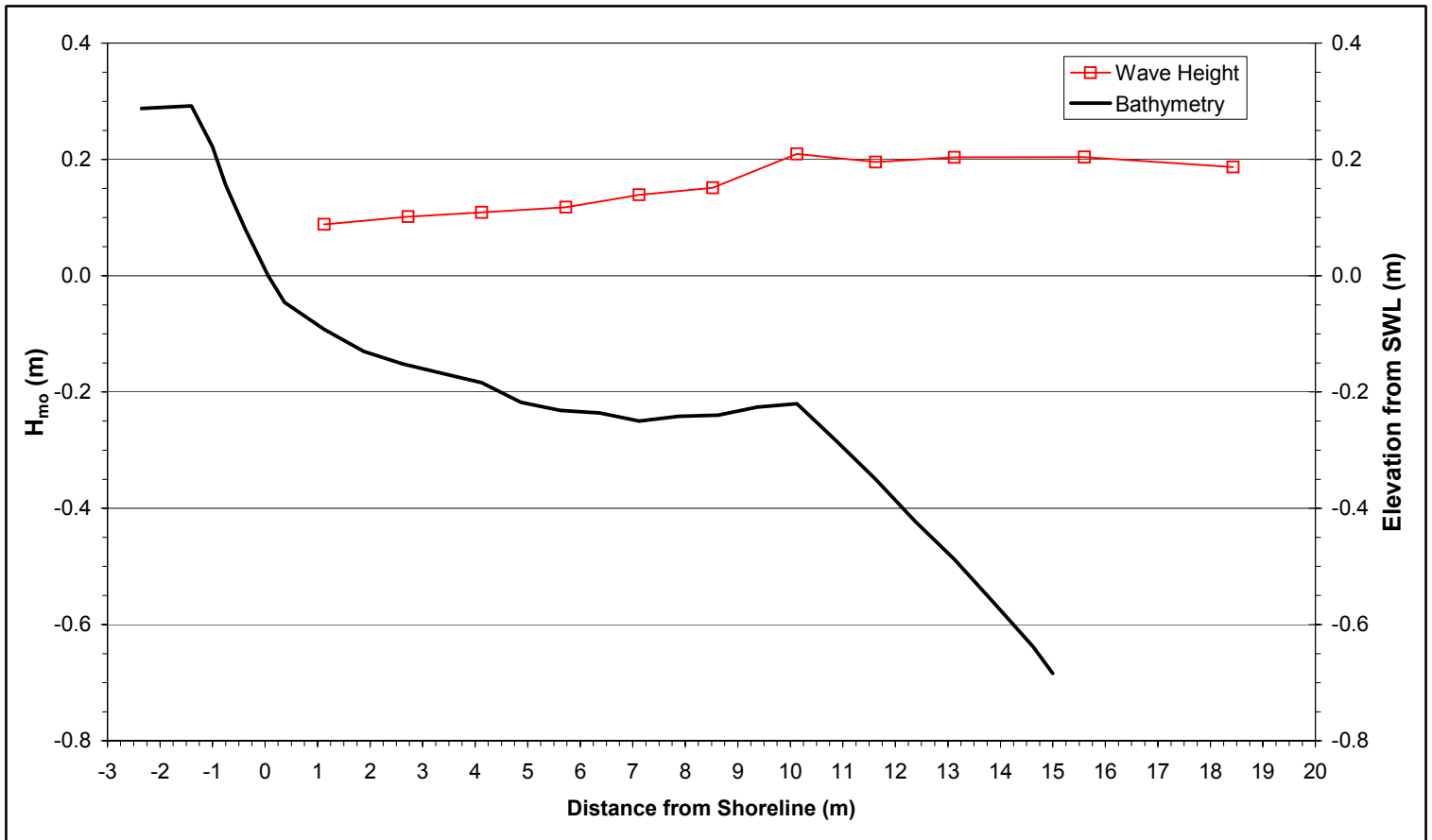

Figure 4. Wave height distribution and beach profile associated with Test 6 
Total LST rate was computed by summing the sediment flux measured in all of the traps. The values presented are given in deposited sand volume assuming a porosity of 40 percent. Measured transport rates are given in Table 2 along with the predicted values based on Equations 1 and 2, which were converted from immersed weight to immersed volume. If the recommended $K$-value of 0.39 is used, the CERC formula (Equation 1) over predicts measured values from the spilling cases by a factor of 8 for Test 1 and nearly 7 for Test 5 . Over estimates are greater than a factor of 3 for both plunging wave cases. The CERC formula produced similar estimates for Test 1 and Test 3 because they have similar breaking wave heights, although breaker types differed. Measured transport rates were nearly three times greater for Test 3 (plunging) than Test 1 (spilling) and more than three times greater for Test 6 (plunging) than Test 5 (spilling). Results using Kamphuis (1991) (Equation 2) produced more consistent estimates with the measured data; differences ranged between 10 percent for Test 1 to 22 percent for Test 6 . The improved estimates of Kamphuis (1991) can in part be attributed to the incorporation of wave period into Equation 2, which influences breaker type. Predictions using the method of Bailard $(1981,1984)$, which considers grain size in the computation of $K$, also gave better estimates than the CERC formula. However, differences ranged from 30 percent (Test 6) to 300 percent (Tests 1 and 5). Equation 5 (del Valle, Medina, and Losada 1993) gave results generally on the same order as the CERC formula.

\begin{tabular}{|c|c|c|c|c|c|}
\hline $\begin{array}{l}\text { Experiment } \\
\text { Number }\end{array}$ & $\begin{array}{l}\text { Measured } \\
\mathrm{m}^{3} / \text { year }\end{array}$ & $\begin{array}{l}\text { CERC Formula }(K=0.39) \\
\mathrm{m}^{3} / \text { year }\end{array}$ & $\begin{array}{l}\text { Kamphuis } \\
\mathrm{m}^{3} / \text { year }\end{array}$ & $\begin{array}{l}\text { Bailard } \\
\mathrm{m}^{3} / \text { year }\end{array}$ & $\begin{array}{l}\text { del Valle et al } \\
\mathrm{m}^{3} / \text { year }\end{array}$ \\
\hline 1 & 2,660 & 20,740 & 2,390 & 10,660 & 20,570 \\
\hline 3 & 7,040 & 22,900 & 6,060 & 14,570 & 33,000 \\
\hline 5 & 1,130 & 8,400 & 1,010 & 4,500 & 7,760 \\
\hline $6^{1}$ & 4,040 & 12,040 & 3,160 & 5,250 & 11,010 \\
\hline
\end{tabular}

Saville (1950) observed that for waves of identical energy levels, greater longshore transport rates occurred for waves having lower wave steepness. Ozhan (1982) found similar results in a laboratory study. Breaker type is a function of wave steepness, and lower steepnesses indicate plunging breakers. In summarizing a review of longshore sediment transport literature, Bodge and Dean (1987) state that longshore sediment transport should somehow depend upon the breaker type. The results shown in Table 2 support these conclusions and indicate that in addition to wave height, breaker type is a factor in estimating LST rates.

Considering the role of breaker type in LST rates, the CERC formula was evaluated based on breaker type. If measured transport rates from Test 1 are used to calibrate the CERC formula, $K=0.05$. Applying this coefficient to the wave conditions of the lower energy spilling case (Test 5) gives a transport rate of $1,080 \mathrm{~m}^{3} /$ year, or a 5 percent difference from the measured rates. Likewise, if the CERC formula is calibrated with transport rates from Test $3, K=0.13$. Applying this coefficient with wave conditions of the lower energy plunging case (Test 6), a transport rate of $3,700 \mathrm{~m}^{3} /$ year is calculated, which is an 8 percent difference compared to measured rates. The improved rates are illustrated in Figure 5, which shows calculated versus 
measured transport rates using the CERC formula with calibrated $K$-values. Additionally, CERC formula estimates using $K=0.39$ and estimates from Kamphuis (1991) are included. The figure indicates that the CERC formula gives reasonable estimates if $K$ is calibrated, and it is applied to similar breaker types. The Kamphuis equation, which includes wave period, a factor that influences breaker type, predicts measured rates well for these cases. However, Figure 5 indicates that the Kamphuis equation tends to underpredict as the LST rate increases. The Kamphuis equation (Equation 2) gives transport rate as a function of $H^{2}$, whereas transport rate using the CERC formula (Equation 1) is a function of $H^{5 / 2}$. For higher waves, Equation 2 will give significantly lower values than Equation 1, and it is unclear if Equation 2 will give accurate results at high-energy conditions.

Unfortunately, historical data are not always available at a location to calibrate $K$. A solution to estimate $K$ at these locations is to use shoreline change data to estimate the LST rate for calibration of $K$. Also, if historical transport data are available at another site that has similar wave conditions, sediment grain sizes, and bathymetry it may be applicable for calibration.

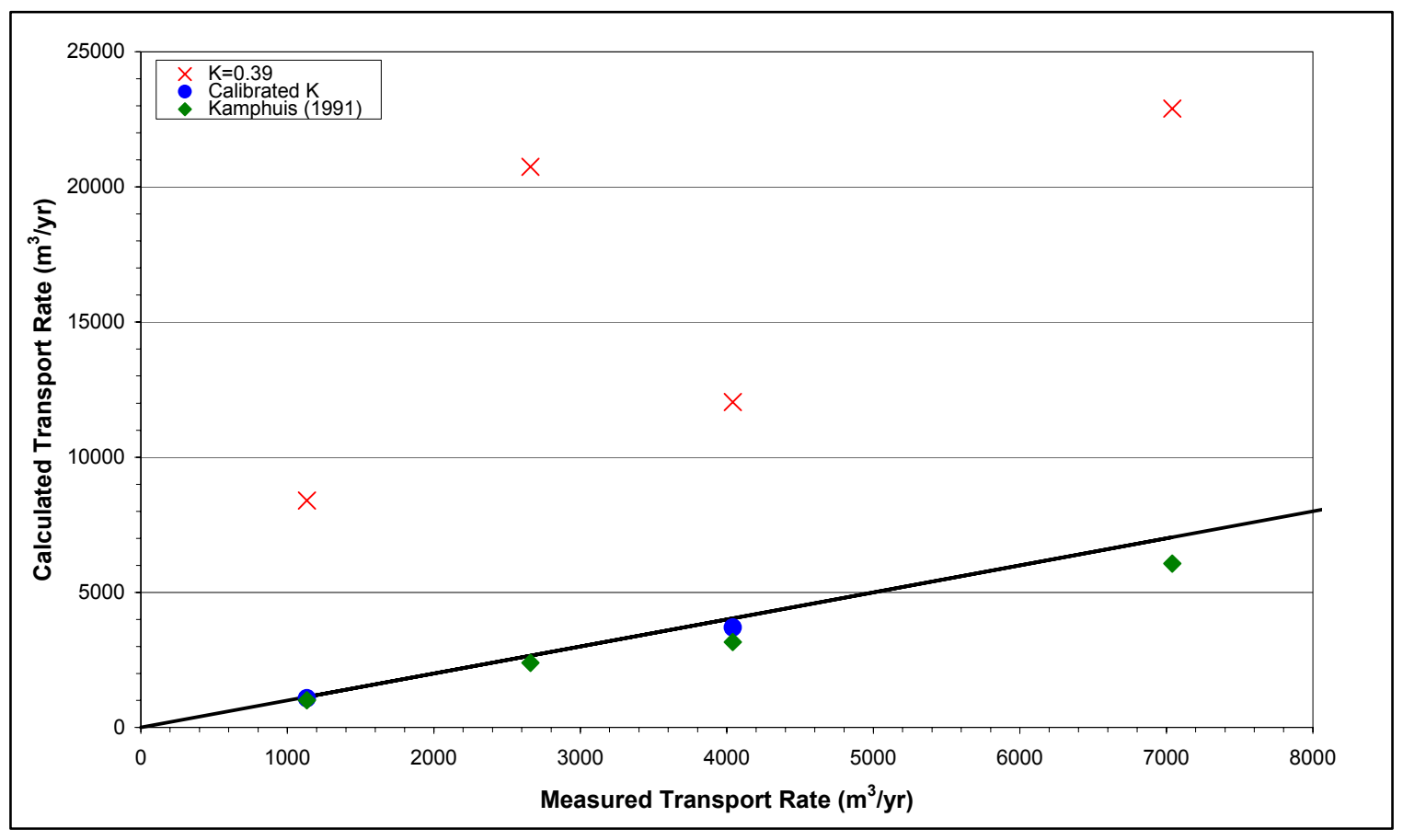

Figure 5. Comparison of calculated to measured transport rates

CROSS-SHORE DISTRIBUTION OF LST: Ongoing research in the LSTF includes investigation of the cross-shore distribution of longshore sediment transport. Longshore sediment flux was calculated from the rate of sand collected in each trap, and plotted as a function of distance from the shoreline in Figure 6 for the experiments listed in Table 1. The figure indicates that there are three distinct zones of transport: incipient breaking zone, inner surf zone, and swash zones. 


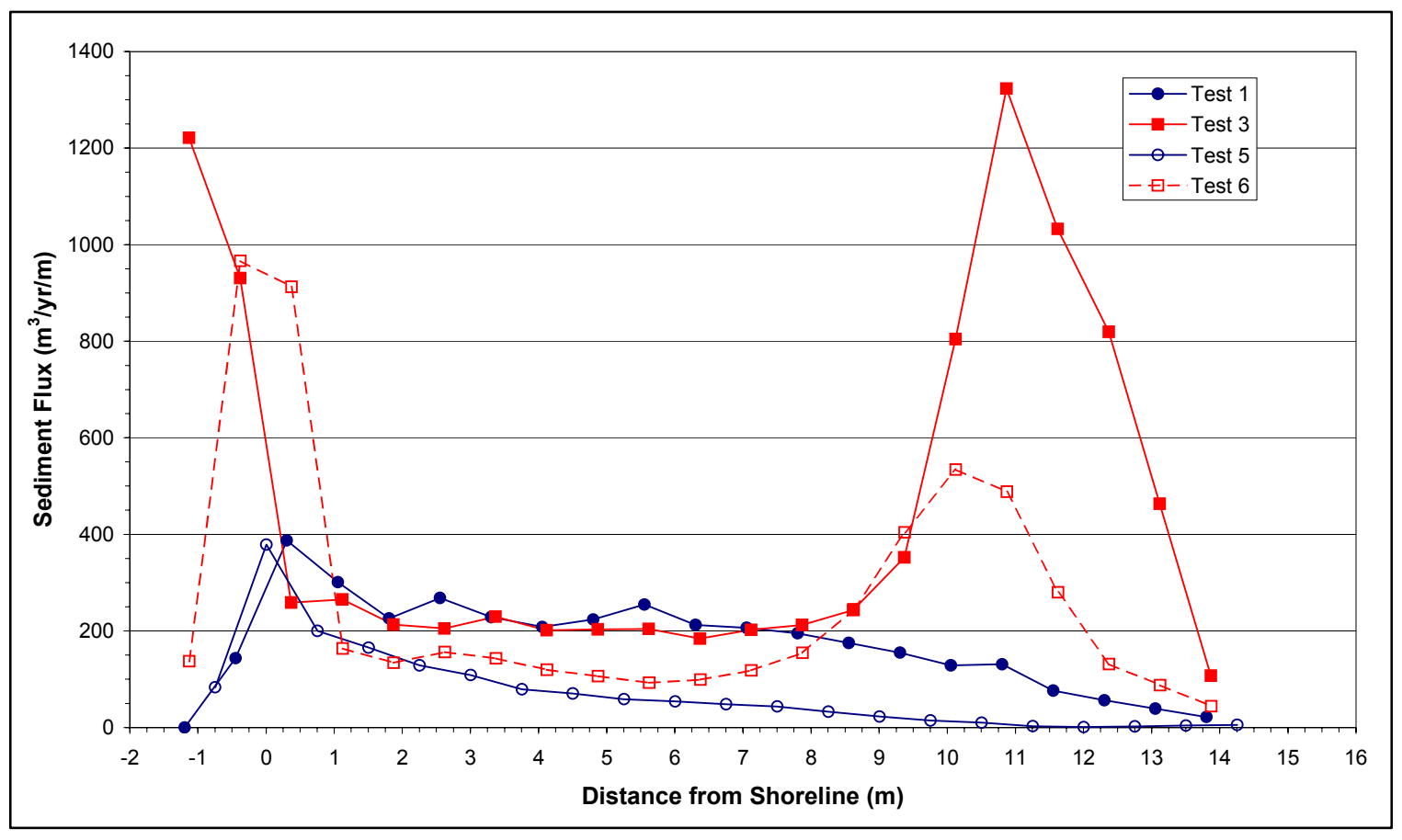

Figure 6. Cross-shore distribution of measured longshore sediment transport

Incipient Breaking Zone. At incipient breaking, a substantial peak in transport occurs for the plunging-wave cases, Tests 3 and 6 . However, an increase in transport is not observed in the spilling-wave cases. The absence of a peak in transport for the spilling cases can be explained as a function of breaker type. Turbulence associated with spilling breakers remains close to the surface in the bore. The jet associated with the large plunging waves penetrated deep into the water column, impacted the bed, and caused sand to be suspended and transported by the longshore current (Wang et al. 2002).

Inner Surf Zone. Figure 7 shows the wave height distribution for the four cases. Tests 1 and 3 have similar heights and similar sediment fluxes in the inner surf zone. Wave heights and sediment fluxes for Tests 5 and 6 are lower in the inner surf zone than the higher energy cases. However, wave heights and sediment flux for Test 6 are slightly higher than those of Test 5 . In the inner surf, energy is saturated and wave height is strongly controlled by depth, and independent of period. The results imply that sediment flux in the inner surf zone is dominated by wave height and independent of period.

Swash Zone. The swash zone was defined as the region where an increase in foreshore slope was observed, which was within $2 \mathrm{~m}$ from the shoreline for the present experiments. There is a peak in transport in the swash zone for all cases, and Figure 6 shows that swash zone transport has a dependence on wave period. For waves having similar incident wave heights but different periods, i.e., Tests 1 and 3, and Tests 5 and 6, swash zone transport is much greater for the longer period cases. In most longshore sediment transport models the swash transport contribution is either completely ignored or merely accounted for as part of the total sediment transport budget (Van Wellen et al. 2000). However, significant swash zone transport rates have been observed in 
field and laboratory studies (Sawaragi and Deguchi 1978, Bodge and Dean 1987), and swash zone transport can account for up to 50 percent of the total LST (Elfrink and Baldock 2002, Van Wellen et al. 2000). For the higher energy cases (Test 1 and Test 3), swash zone transport accounts for a third of the total transport. However, for the lower energy cases (Test 5 and Test 6), swash zone transport accounts for 40 to 60 percent of the total transport. Additionally, the reduction in total transport between the higher and lower spilling cases (Test 1 and Test 5) was a factor of 2.3, but the reduction in swash transport was only 1.2. The reduction in total transport between higher and lower plunging cases (Test 3 and Test 6) was 1.7, but the reduction in swash zone transport was 1.3. Although data are limited, this implies that swash zone transport contributes more to the total transport rate for smaller scales, and conversely, as incident wave height increases the contribution of swash transport to total transport is less. This observation agrees with findings of Elfrink and Baldock (2002), who found that the relative contribution of swash zone transport was greater during calm conditions than during storms. The results indicate that the role of swash zone transport can be significant, especially in lower energy environments, which would include small-scale physical models.

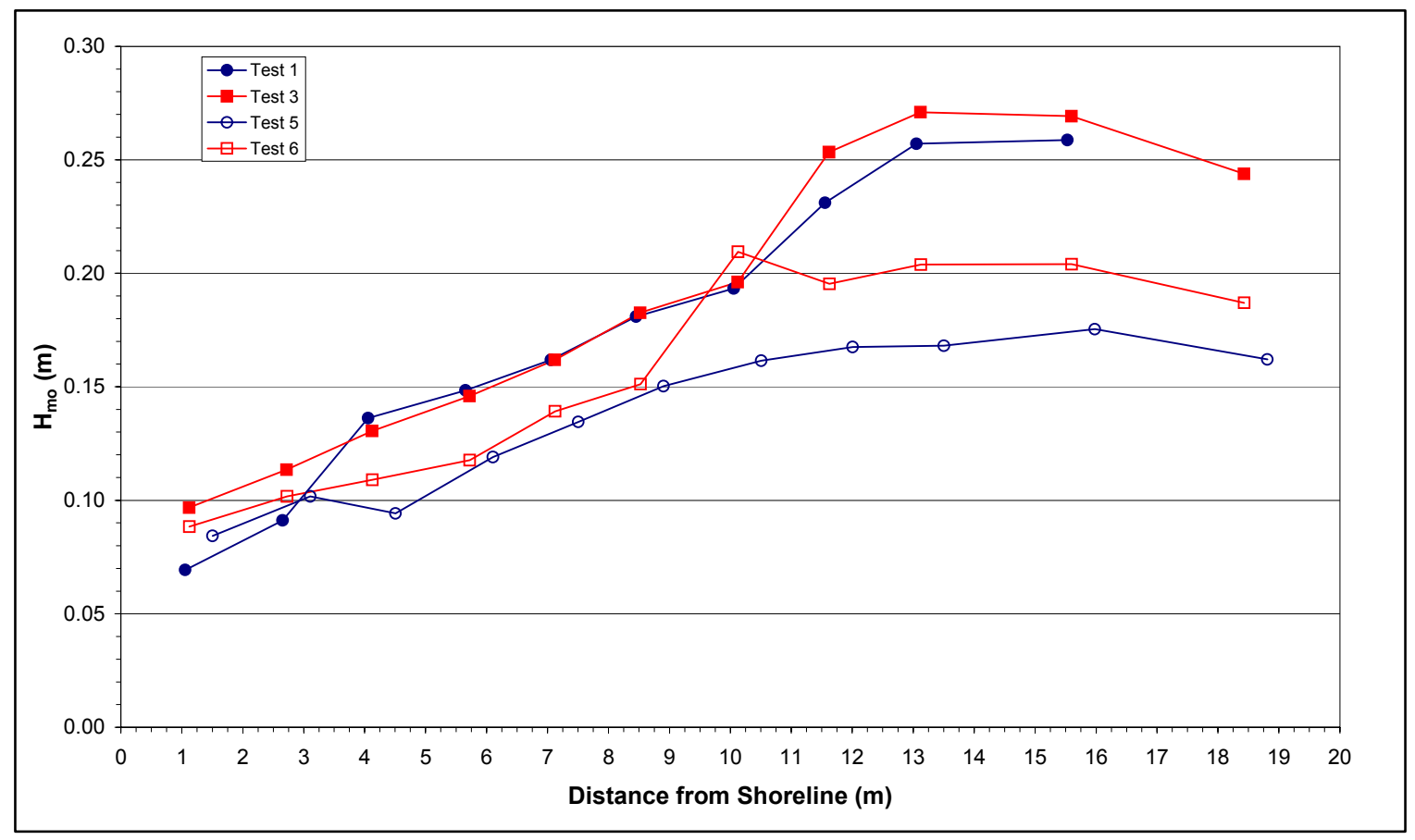

Figure 7. Cross-shore distribution of wave heights

In addition, results from the present study have implications to field measurements of LST. Although swash zone transport measurements are difficult to obtain in the field, the results indicate that it is necessary to include swash zone transport to obtain accurate measurements of total longshore sediment transport. For example, if swash zone transport was not measured in the present study, the overestimates of the CERC formula increase by 50 to 275 percent.

SUMMARY AND CONCLUSIONS: Measurements of LST rates were performed in a largescale physical model for four incident wave conditions that varied by breaker type and incident 
energy. Measured transport rates were compared to estimates computed with the CERC formula (Kamphuis 1991; Bailard 1981, 1984; del Valle, Medina, and Losada 1993). The CERC formula, in particular the coefficient $K$, was evaluated. It was found that the CERC formula overestimated measurements by a factor of 7 to 8 for spilling breakers, and more than a factor of 3 for plunging breakers. The CERC formula is not sensitive to breaker type, which was found to be an important factor in determining total LST rates. If the coefficient $K$ of the CERC formula was calibrated with measured data and applied to similar breaker types, differences were reduced to 7 percent. Estimates using the Kamphuis equation, which includes wave period, that influences wave breaking, were good with differences ranging from 1 to 22 percent. The findings indicate that total LST rate is a function of breaker type, and the CERC formula performs well if $K$ is calibrated and applied to wave conditions having similar breaker type.

The cross-shore distribution of longshore sediment transport indicated three distinct zones of transport: the incipient breaker zone, the inner surf zone, and the swash zone. A peak in transport occurred for plunging waves in the incipient breaker zone, indicating that this breaker type suspends more sediment for transport. Breaker type is a function of wave height, period, and beach slope (Galvin 1968). Transport in the inner surf zone indicated that wave height was the dominating factor and independent of wave period. Swash zone transport, which accounted for a significant percentage of the total transport, showed a dependence on wave height, period, and beach slope.

POINTS OF CONTACT: Questions about this CHETN can be addressed to Mr. Ernest R. Smith (601-634-4030, Fax 601-634-4314, e-mail: Ernest.R.Smith@erdc.usace.army.mil,. The contributions of William Halford, David Daily, and Tim Nisley, who provided technical support to this study, are gratefully acknowledged.

\section{REFERENCES}

Bailard, J. A. (1981). "An energetics total load sediment transport model for a plane sloping beach," Journal of Geophsical Research. 86 (C11), 10938-10954.

Bailard, J. A. (1984). “A simplified model for longshore sediment transport.” Proceedings of the 19 ${ }^{\text {th }}$ International Conference on Coastal Engineering, ASCE, 1454-1470.

Bodge, K. R., and Dean, R. G. (1987). "Short-term impoundment of longshore transport." Proceedings of Coastal Sediments '87. ASCE, New York, 468-483.

Coastal Engineering Manual. (2002). “Longshore Sediment Transport,” Part 3-2, Washington, DC.

del Valle, R., Medina, R., and Losada, M. A. (1993). "Dependence of coefficient $K$ on grain size," Technical Note No. 3062, Journal of Waterway, Port, Coastal, and Ocean Engineering 119 (5), 568-574.

Elfrink, B., and Baldock, T. (2002). "Hydrodynamics and sediment transport in the swash zone: A review and perspectives," Coastal Engineering 45, 149-167.

Fowler, J. E., Rosati, J. D., Hamilton, D. G., and Smith, J. M. (1995). "Development of a large-scale laboratory facility for longshore sediment transport research," The CERCular, CERC-95-2, U.S. Army Engineer Waterways Experiment Station, Vicksburg, MS.

Galvin, C. J. (1968). "Breaker type classifications of three laboratory beaches," Journal of Geophysical Research $73,3651-3659$.

Hallermeier, R. J. (1981). “Terminal settling velocity of commonly occurring sand grains,” Sedimentology (28). 


\section{ERDC/CHL CHETN-IV-62 \\ September 2004}

Hamilton, D. G., Ebersole, B. A., Smith, E. R., and Wang, P. (2001). "Development of a large-scale laboratory facility for sediment transport research," Technical Report, U.S. Army Engineer Research and Development Center, Vicksburg, MS.

Hamilton, D. G., and Ebersole, B. A. (2001). "Establishing uniform longshore currents in a large-scale laboratory facility," Coastal Engineering 42, 199-218.

Kamphuis, J. W. (1991). “Alongshore sediment transport rate,” Journal of Waterways, Port, Coastal and Ocean Engineering ASCE, 117(6), 624-641.

Kamphuis, J. W. (2002). "Alongshore transport of sand." Proceedings of the 28th International Conference on Coastal Engineering. ASCE, 2478-2490.

Komar, P. D. (1988). "Environmental controls on littoral sand transport." Proceedings of the 21st International Conference on Coastal Engineering. ASCE, 1238-1252.

Komar, P. D., and Inman, D. L. (1970). "Longshore sand transport on beaches," Journal of Geophysical Research 75(30), 5514-5527.

Miller, H. C. (1998). "Comparison of storm longshore transport rates to predictions." Proceedings of the 26th Conference on Coastal Engineering. ASCE, 2954-2967.

Nordstrom, K. F. (1992). Estuarine beaches. Elsevier Applied Science, 225 pp.

Ozhan, E. (1982). "Laboratory study of breaker type effect of groins on the rate of littoral transport." Proc, Euromech 156: Mechanics of Sediment Transport. B. M. Sumer and A. Muler, ed.

Rattanapitikon, W., and Shibayama, T. (2000). "Verification and modification of breaker height formulas," Coastal Engineering Journal 42 (4), 381-406.

Saville, T. (1950). "Model study of sand transport along an infinitely long, straight beach," Trans., American Geophysical Union 31 (4), 555-565.

Sawaragi, T., and Deguchi, I. (1978). "Distribution of sand transport rate across the surf zone." Proceedings of the 16th Conference on Coastal Engineering. ASCE, 1596-1613.

Schoonees, J. S., and Theron, A. K. (1993). "Review of the field data base for longshore sediment transport," Coastal Engineering 19, 1-25.

Schoonees, J. S., and Theron, A. K. (1994). "Accuracy and applicability of the SPM longshore transport formula." Proceedings of the 24th Coastal Engineering Conference. ASCE, 2595-2609.

Shore Protection Manual. (1984). U.S. Government Printing Office, Washington, DC.

Smith, E. R., and Kraus, N. C. (1991). "Laboratory study of wave breaking over bars and artificial reefs," Journal of Waterway, Port, Coastal and Ocean Engineering ASCE, 117, 307-325.

Sunamura, T., and Kraus, N. C. (1985). "Prediction of average mixing depth of sediment in the surf zone," Marine Geology 62, 1-12.

Van Wellen, E., Baldock, T., Chadwick, A., and Simmonds, D. (2000). "STRAND - a model for longshore sediment transport in the swash zone." Proceedings of the 27th Conference on Coastal Engineering. ASCE, 3139-3150.

Walton, T. L. (1979). “Littoral sand transport on beaches,” PhD. diss, University of Florida, Gainesville, FL.

Walton, T. L., and Chiu, T. (1979). "A review of analytical techniques to solve the sand transport equation and some simplified solutions." Proceedings of Coastal Structures '79. ASCE, 809-837.

Wang, P., Kraus, N. C., and Davis, R. A., Jr. (1998). "Total rate of longshore sediment transport in the surf zone: Field measurements and empirical predictions," Journal of Coastal Research 14(1), 269-283.

Wang, P., and Kraus, N. C. (1999). "Longshore sediment transport rate measured by short-term impoundment," Journal of Waterway, Port, Coastal and Ocean Engineering ASCE, 125, 118-126. 
Wang, P., Ebersole, B. A., Smith, E. R., and Johnson, B. D. (2002). "Temporal and spatial variations of surf-zone currents and suspended sediment concentration," Coastal Engineering, (46), 175-211.

Weggel, J. R. (1972). "Maximum breaker height," Journal of the Waterways, Harbors and Coastal Engineering Division ASCE, 98 (WW4), 529-548.

NOTE: The contents of this technical note are not to be used for advertising, publication, or promotional purposes. Citation of trade names does not constitute an official endorsement or approval of the use of such products. 